Check for updates

Cite this: J. Anal. At. Spectrom., 2020 35,2231

\section{Needles in haystacks: using fast-response LA chambers and ICP-TOF-MS to identify asbestos fibres in malignant mesothelioma models $\uparrow$}

\author{
Calum J. Greenhalgh, $\$^{\mathrm{a}}$ Oana M. Voloaca, $\$^{\mathrm{b}}$ Phil Shaw, ${ }^{\mathrm{c}}$ Ariane Donard, ${ }^{\mathrm{c}}$

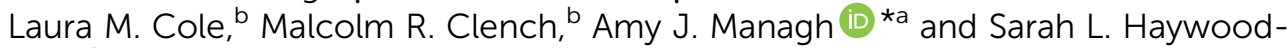 \\ Small
}

\begin{abstract}
Malignant mesothelioma is an aggressive cancer associated with exposure to asbestos. Diagnosis of mesothelioma and other related lung diseases remains elusive due to difficulties surrounding identification and quantification of asbestos fibres in lung tissue. This article presents a laser ablationinductively coupled plasma-mass spectrometry (LA-ICP-MS) method to identify asbestos fibres in cellular models of mesothelioma. Use of a high-speed laser ablation system enabled rapid imaging of the samples with a lateral resolution of $3 \mu \mathrm{m}$, whilst use of a prototype time-of-flight ICP-MS provided pseudo-simultaneous detection of the elements between mass $23(\mathrm{Na})$ and mass $238(\mathrm{U})$. Three forms of asbestos fibre (actinolite, amosite and crocidolite) were distinguished from a non-asbestos control (wollastonite) based on their elemental profile, which demonstrated that LA-ICP-MS could be a viable technique for identification of asbestos fibres in clinical research samples.
\end{abstract}

Received 29th May 2020

Accepted 14th July 2020

DOI: $10.1039 / \mathrm{d} 0 \mathrm{ja} 00268 \mathrm{~b}$

rsc.li/jaas

\section{Introduction}

Malignant pleural mesothelioma (MPM) is an aggressive cancer whose pathogenesis is linked with occupational and environmental exposure to asbestos fibres. ${ }^{1}$ The prognosis of mesothelioma is poor due to the difficulty of making diagnosis in the early stage, the rapid progression, high invasiveness and lack of effective treatment. ${ }^{2}$ As the global incidence of mesothelioma is expected to increase over the next two decades, ${ }^{3}$ difficulties remain in relation to diagnosis, notably due to the lack of biomarkers and impeded identification and quantification of asbestos fibres in lung tissue.

In the UK, asbestos can be found in many industrial or residential buildings built or refurbished before the year 2000 . The term "asbestos" is a general term and refers to silicate minerals that are composed of polyfilamentous bundles of long, flexible fibres with a small diameter. ${ }^{3}$ These can be easily inhaled when broken into fibrils. The mineral fibres are classified into two subgroups: (i) the amphiboles, a group of rodlike fibres including amosite, crocidolite, anthophyllite, actinolite and tremolite; and (ii) the serpentine group, consisting of

${ }^{a}$ Department of Chemistry, Loughborough University, LE11 3TU, UK. E-mail: A.J. Managh@lboro.ac.uk

${ }^{b}$ Department of Biosciences and Chemistry, Sheffield Hallam University, S1 1WB, UK ${ }^{c} N u$ Instruments, Unit 74, Clywedog Rd S, Wrexham, LL13 9XS, UK

$\dagger$ Electronic supplementary information (ESI) available: Sector-field imaging data, raw spectrum of the full mass range. See DOI: $10.1039 /$ d0ja00268b

\$ These authors contributed equally. chrysotile. ${ }^{4}$ Their potency of inducing asbestos-related diseases such as pleural plaques, asbestosis and MPM reportedly differs from one fibre to another due to differences in chemical structure, and therefore in solubility of the fibres in the lung. ${ }^{3}$

Detection of asbestos fibres using microscopic approaches is often inadequate. Sometimes fibres are undetectable, even in patients with heavy asbestos exposure. ${ }^{5}$ The routine quantification method uses phase contrast microscopy to count the mineral fibres that are longer than $5 \mu \mathrm{m}$, thinner than $3 \mu \mathrm{m}$, and have aspect ratios larger than $3: 1 .{ }^{6}$ However, this method cannot detect shorter or thicker fibres and cannot distinguish between asbestos and other natural-occurring or man-made fibres, making some fibres considerably hard to detect and quantify. ${ }^{6}$ Another established method involves the use of transmission electron microscopy, following the International Standards Organisation (ISO) method for characterisation of airborne asbestos fibres. ${ }^{7}$ However, differentiation between fibre types in more complex matrices, such as biological tissue, remains challenging because fibre visibility and orientation may be hindered.

Asbestos fibres are composed of silicon and other elements, such as $\mathrm{Mg}$, Ca and $\mathrm{Fe}$, in varying proportions depending on fibre type. Consequently, there have been a small number of attempts to use elemental analysis, rather than optical properties, to distinguish between asbestos fibres. Pascolo et al., demonstrated the use of X-ray fluorescence (XRF) to analyse asbestos exposed lung tissue for identification of sub micrometre diameter fibres based upon $\mathrm{Ca}, \mathrm{Fe}$ and $\mathrm{Si}$ elemental profiles. ${ }^{8} \mathrm{X}$-ray absorption near edge spectroscopy (XANES) has 


\section{Actinolite}
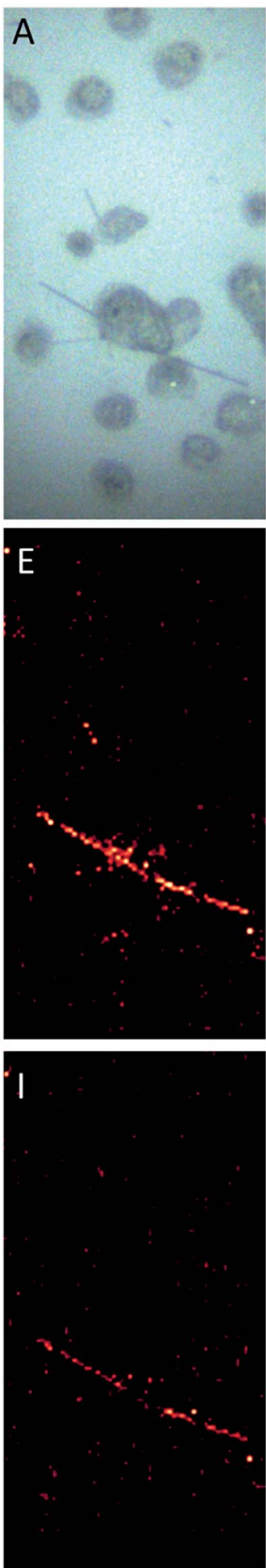

Amosite
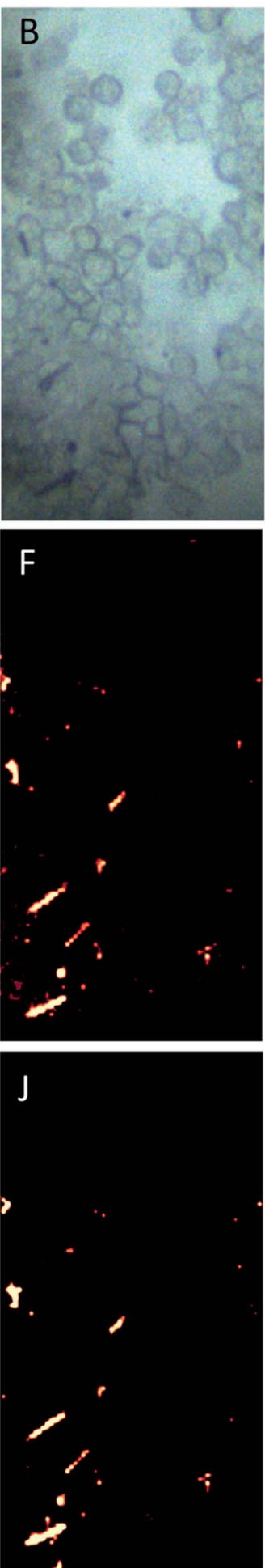

Crocidolite
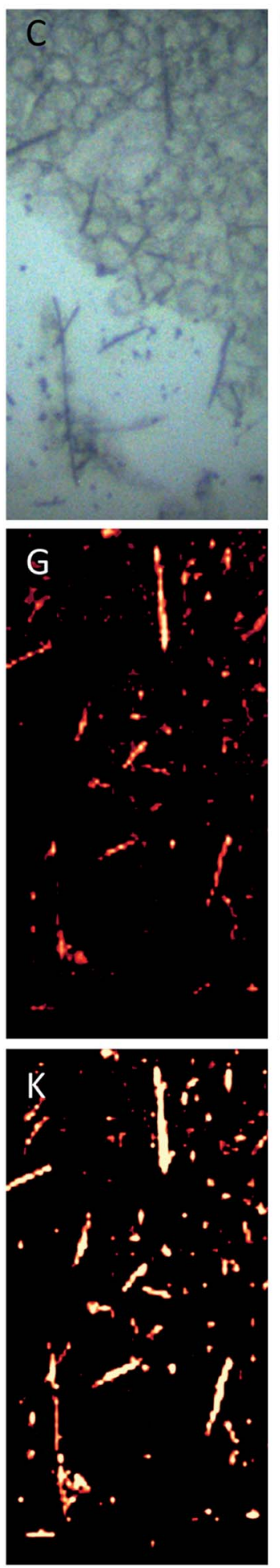

\section{Wollastonite}
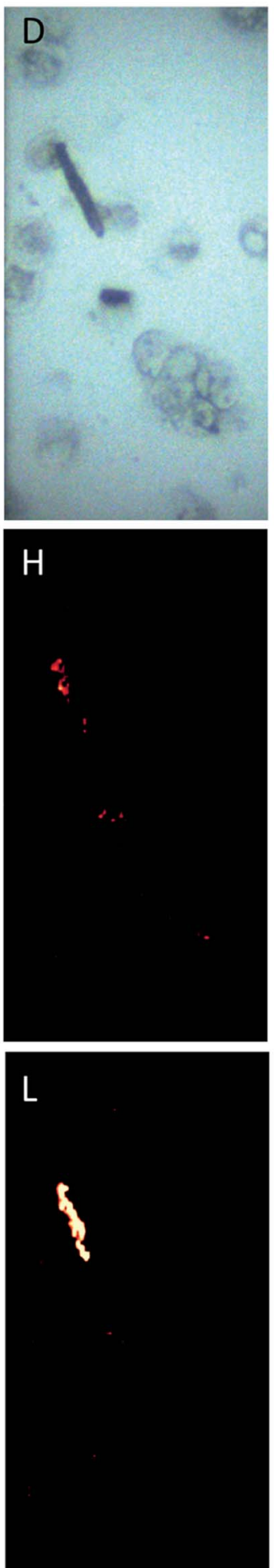

${ }^{24} \mathrm{Mg} / \mathrm{CPS}$

$\geq 5000$

4600

4200

3800

3400

3000

2600

2200

1800

1400

$\leq 1000$

${ }^{28} \mathrm{Si} / \mathrm{CPS}$

$\geq 30000$

27300

24600

21900

19200

16500

13800

11100

8400

5700

$\leq 3000$

Fig. 1 Microscopic images of MSTO-211H cells spiked with actinoloite, amosite, crocidolite and wollastonite fibres (panels (A), (B), (C) and (D) respectively). Fibres are visible as dark needle shaped objects in the microscopic images. LA-ICP-MS images of the magnesium and silicon distribution across the samples are shown in panels $(E-H)$ and $(I-L)$ respectively. A $400 \times 200 \mu m$ area was sampled for each fibre type.

also been used to complement XRF analysis. ${ }^{9}$ Transmission electron microscopy has been used in conjunction with energy dispersive X-ray (EDX) spectroscopy to identify fibres with a length and diameter as low as $0.1 \mu \mathrm{m}$, which optical microscopy could not detect. ${ }^{10}$ Based upon multielement analysis of Si, $\mathrm{Fe}, \mathrm{Mg}$ and $\mathrm{Al}$ the specific form amosite was identified in 
ultrathin histological sections of lung tissue. ${ }^{\mathbf{1 0}}$ In another analytical approach, secondary ion mass spectrometry was able to detect fibres as small as $1 \times 5 \mu \mathrm{m}$ that had been collected on a membrane, providing spatial information on $\mathrm{Mg}$, $\mathrm{Si}$ and $\mathrm{Ca} .{ }^{11}$

Laser ablation inductively coupled plasma mass spectrometry (LA-ICP-MS) provides information on the spatially resolved elemental distribution within a sample. The technique has been utilised for a broad range of biological applications; from the imaging of endogenous elements, such as $\mathrm{Ca}, \mathrm{Zn}, \mathrm{Cu}$, and $\mathrm{Fe}$ in human and animal tissues, ${ }^{\mathbf{1 2 - 1 4}}$ to revealing the distribution of platinum anticancer drugs in tumours and tissue. ${ }^{15,16}$ In the last decade, a focus on ablation cell designs has led to dramatic improvements in transport of the ablated aerosol. Improved cell geometries have given rise to increases in absolute sensitivity and faster analysis times. ${ }^{\mathbf{1 7 - 1 9}}$ The latest generation systems also offer improved spatial resolution, with lateral resolutions of a few $\mu \mathrm{m}$ now common, ${ }^{20,21}$ compared to typical resolutions of 5-100 $\mu \mathrm{m}$ achieved with older designs. The drive towards use of higher speed LA systems has contributed to a rise in the popularity of time-of-flight (TOF) ICP-MS systems for imaging applications. ${ }^{\mathbf{1 9 , 2 2 - 2 4}}$ TOF mass analysers enable pseudosimultaneous detection of the full mass range, which is advantageous for analysis of the fast transient signals from modern LA units. These recent technological developments have therefore expanded the capability of LA-ICP-MS to the point where it now warrants investigation as a tool to rapidly detect and identify fibres in tissue. In the present work, a highspeed LA platform and a prototype ICP-TOF-MS were employed together for the first time to evaluate the potential for rapid multi-elemental detection of fibres. Three types of asbestos fibre and a non-asbestos control were located and identified in 2D and 3D cellular models of mesothelioma.

\section{Experimental}

\section{Cell culture}

Human mesothelioma cells, MSTO-211H (ATCC, UK) were cultured and maintained at $37{ }^{\circ} \mathrm{C}$ in a humidified atmosphere with $5 \% \mathrm{CO}_{2}$ in RPMI 1640 medium supplemented with $10 \%$ (v/ v) heat-inactivated foetal bovine serum and $1 \%(\mathrm{v} / \mathrm{v})$ penicillin/ streptomycin. The cultures were grown and harvested according to established cell culture protocols. ${ }^{25}$ All cell culture materials were supplied by Gibco, Life Technologies ${ }^{\mathrm{TM}}$, CA, USA. All cells were confirmed to be negative for mycoplasma every three months using the MycoAlert ${ }^{\mathrm{TM}}$ Mycoplasma Detection Kit (LONZA, Switzerland).

\section{Asbestos fibres}

Actinolite, amosite, crocidolite and wollastonite fibres were supplied by Health and Safety Laboratories (UK) and were kindly donated by Santia Asbestos Management Ltd. They were prepared in PBS solution to a stock concentration of $1 \mathrm{mg} \mathrm{mL}{ }^{-1}$. For health and safety reasons, fibres were handled only in specially designed laminar flow hoods (Santia Asbestos Management Ltd. laboratories) until they were mixed into solutions. The fibre solutions were sterilised at $121{ }^{\circ} \mathrm{C}$ in an autoclave and stored at room temperature in PBS solutions. Prior to treatment, the solutions were passed through a 22gauge needle 5 times for separation of the fibrils.

\section{Cell preparation for LA-ICP-MS}

For LA-ICP-MS analysis of $2 \mathrm{D}$ cultures, aliquots of $10 \times 10^{4}$ MSTO-211H cells per well were seeded in 6 well plates, with each well exposed to $3 \mu \mathrm{g} \mathrm{mL}^{-1}$ solutions of a different fibre type. After $24 \mathrm{~h}$, cells were harvested and $200 \mu \mathrm{L}$ of the cell suspensions $\left(5 \times 10^{4}\right.$ cells per $\left.\mathrm{mL}\right)$ were cytospun at $100 \mathrm{~g}$ for 3 minutes onto plastic slides. For the $3 \mathrm{D}$ cell plugs, $1 \times 10^{7}$ cells were harvested, centrifuged and treated with $100 \mu \mathrm{L}$ of the fibre solutions, as required, before embedding in hydroxypropyl methylcellulose (HMPC)/polyvinylpyrrolidone (PVP) media (3:1 ratio) and flash frozen in liquid nitrogen. Finally, the material was cryosectioned onto plastic slides to produce $12 \mu \mathrm{m}$ sections, before introduction into the LA-ICP-MS instrument.

\section{LA-ICP-SF-MS}

Preliminary experiments were performed using a NWR193 laser ablation system (Elemental Scientific Lasers, Bozeman, Montana), coupled to an AttoM ES sector-field ICP-MS (Nu Instruments, Wrexham, UK). For the initial experiments, the laser ablation system was equipped with the standard TwoVol2 chamber which provided a single laser shot signal width of approximately $400-600 \mathrm{~ms}$ at full width $10 \%$ maximum. A helium gas flow of 1-1.2 $\mathrm{L} \mathrm{min}^{-1}$ was used through the ablation chamber, with an argon make-up flow of $0.6-0.8 \mathrm{~L} \mathrm{~min}{ }^{-1}$ introduced through a t-piece downstream of the cell and approximately $5 \mathrm{~cm}$ from the connection to the ICP torch. A laser spot diameter of $3 \mu \mathrm{m}, 10 \mathrm{~Hz}$ repetition frequency, $30 \mu \mathrm{m}$ $\mathrm{s}^{-1}$ scan speed and $1 \mathrm{~J} \mathrm{~cm}^{-2}$ fluence were used during ablation. The analysis was performed using FastScan mode ${ }^{26}$ where the magnet mass position is fixed and electrical deflectors change the measured mass position over $-15 \%$ to $+25 \%$ of the parked mass position in $70 \mu \mathrm{s}$ per jump, with a dwell time of $250 \mu \mathrm{s}$ per isotope. Using this data acquisition method a range between ${ }^{23} \mathrm{Na}$ and ${ }^{33} \mathrm{Si}$ was scanned every $20 \mathrm{~ms}$ for an average of 10 sweeps of the mass range for each acquisition. A trigger cable was also connected between the two systems, with a trigger signal used to demark the start of each ablation line used to build up the image.

\section{LA-ICP-TOF-MS}

A NWR193 laser ablation system (Elemental Scientific Lasers, Bozeman, Montana) was coupled to a Vitesse time-of-flight ICPMS (Nu Instruments, Wrexham, UK). The LA system incorporated a prototype TwoVol3 chamber configured with the imaging cup and was fitted with a Dual Concentric Injector (DCI) for fast washout. ${ }^{17}$ Helium gas flows of $1.2 \mathrm{~L} \mathrm{~min}^{-1}$ and $0.55 \mathrm{~L} \mathrm{~min}^{-1}$ were used through the cup and the outer chamber respectively, with an argon gas flow of $0.7 \mathrm{~L} \mathrm{~min}^{-1}$ introduced through the DCI. The laser ablation parameters were as follows: $3 \mu \mathrm{m}$ spot diameter, $50 \mathrm{~Hz}$ repetition frequency, $150 \mu \mathrm{m} \mathrm{s}^{-1}$ scan speed, $\sim 4 \mathrm{~J} \mathrm{~cm}^{-2}$ fluence. These parameters were chosen to ensure baseline separated signals and provide sampling of 

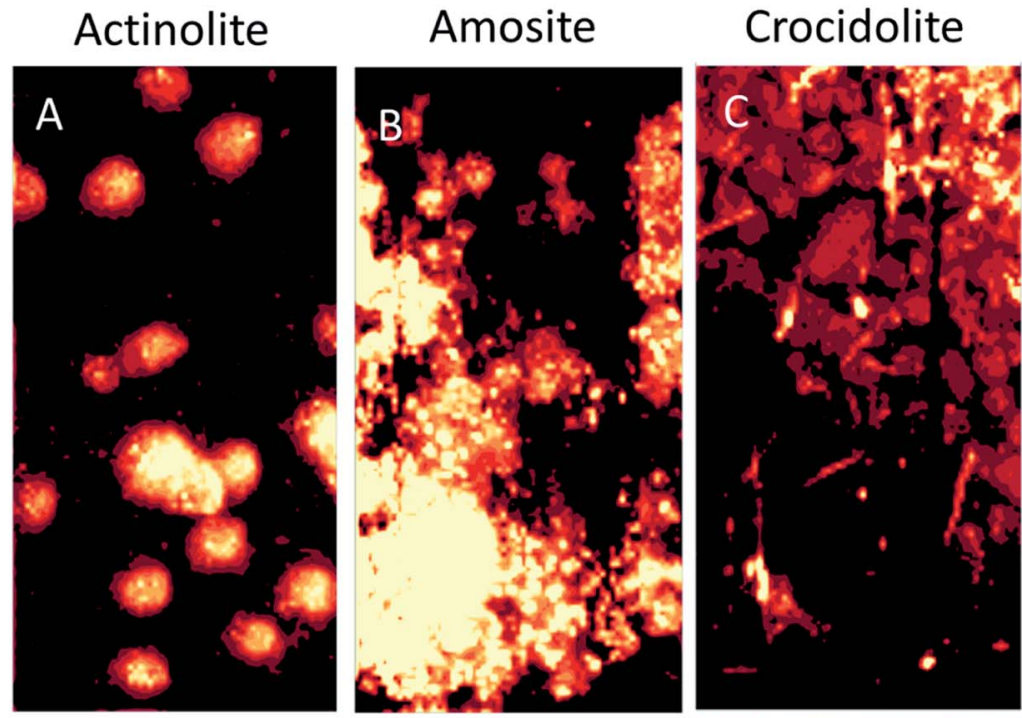

\section{Wollastonite}
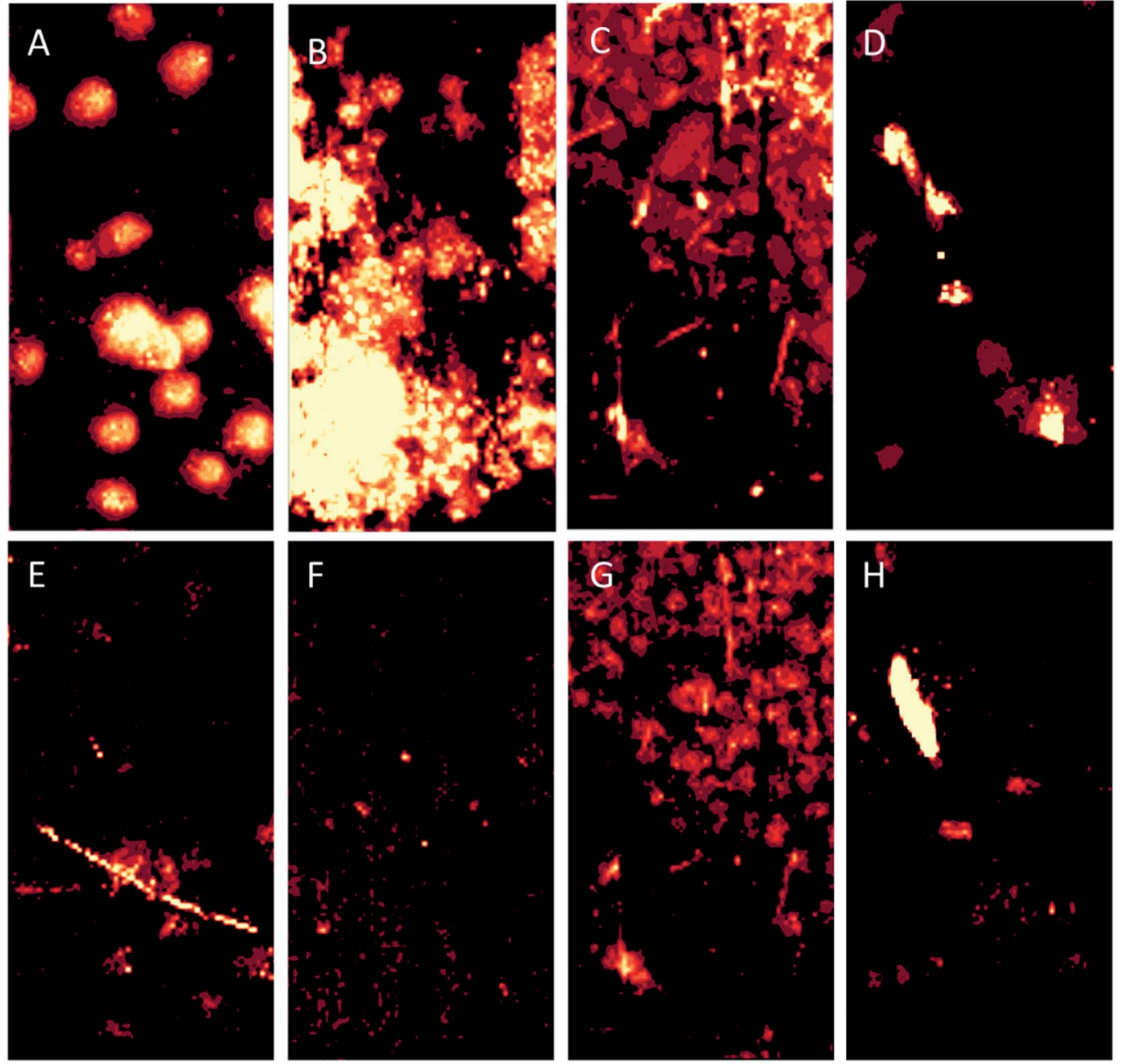

${ }^{23} \mathrm{Na} / \mathrm{CPS}$
50000

45000

40000

35000

30000

25000

20000

15000

10000

5000

$\square_{0}$
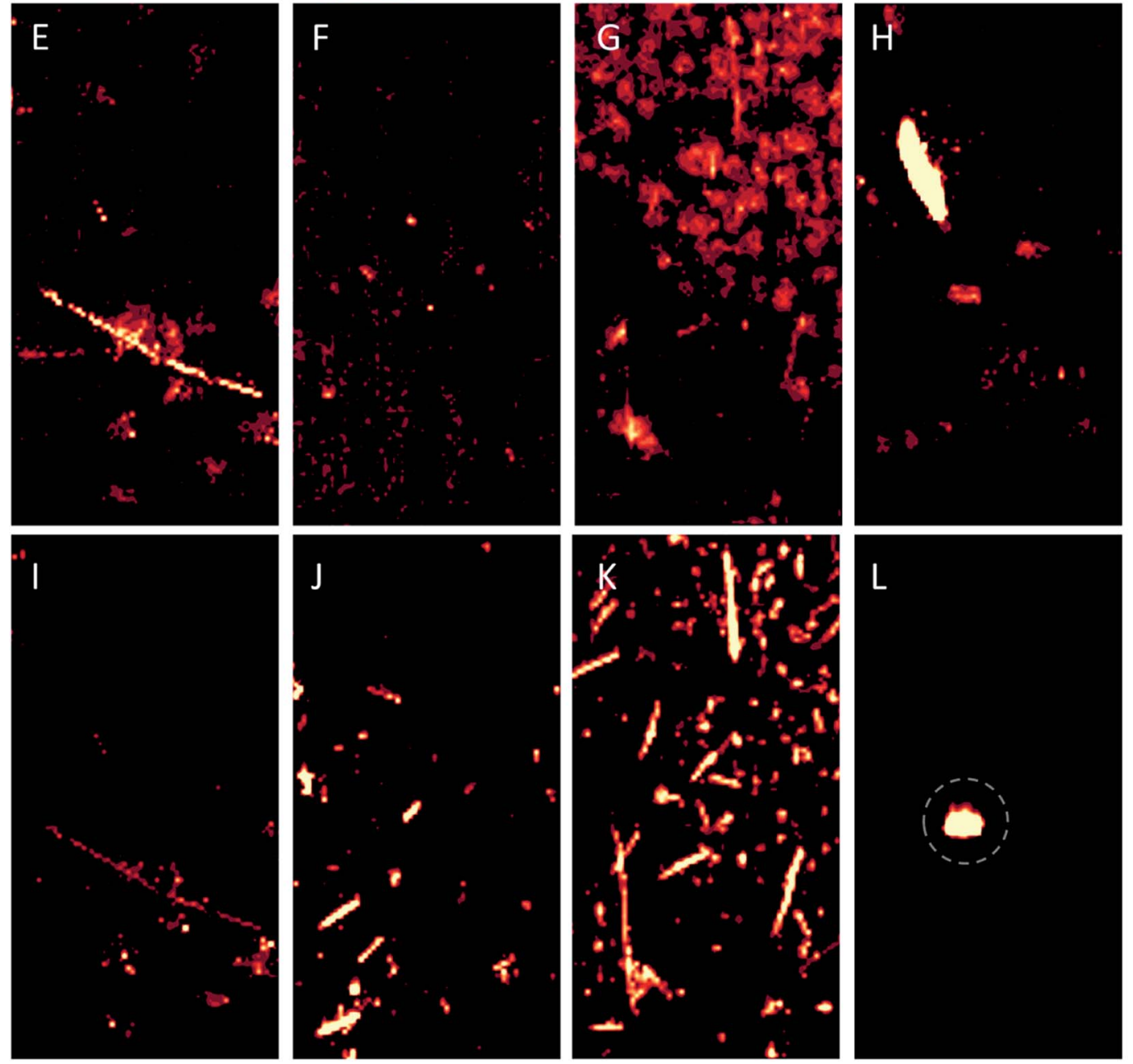
${ }^{40} \mathrm{Ca} / \mathrm{CPS}$
$\geq 15000$

13500

12000

10500

9000

7500

6000

4500

3000

1500

0

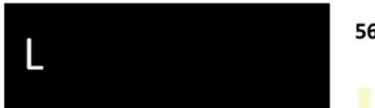

${ }^{56} \mathrm{Fe} / \mathrm{CPS}$

$\geq 200000$

180000

160000

140000

120000

100000

80000

60000

40000

20000

Fig. 2 LA-ICP-MS images of the cell samples shown in panels (A-D) of Fig. 1, showing the sodium (A-D), calcium (E-H) and iron (I-L) distribution across the samples. A $400 \times 200 \mu \mathrm{m}$ area was sampled for each fibre type. The sodium signal shows the location of cells in the images, whilst the needle shaped fibres are clearly visible in the iron and/or calcium images. The circled region in the lower right panel is unlikely to be a wollastonite fibre because it lacks the of characteristic silicon signal. Based on the elements found in this region, this is likely to be a piece of debris resulting from the sample preparation process. 
a fresh, non-overlapping location with each laser shot. Due to the geometry of the laboratory, approximately 1 metre of $0.8 \mathrm{~mm}$ i.d. PEEK tubing was required to connect the LA and ICP-MS units. A trigger cable was also connected between the two systems, with a trigger signal used to demark the time point of each laser shot. The mass spectrometer employed an alwayson collision-reaction cell, which used hydrogen flow of $5 \mathrm{sccm}$ and helium flow of $5 \mathrm{sccm}$ to remove nitrogen, argon and their related polyatomic interferences. This allowed the major isotopes of ${ }^{28} \mathrm{Si},{ }^{39} \mathrm{~K},{ }^{40} \mathrm{Ca}$ and ${ }^{56} \mathrm{Fe}$ to be used, improving the signal to background levels seen in the images. The mass spectrometer method was set to measure between $\mathrm{Na}$ and $\mathrm{U}$ every $25.5 \mu$ s. The resulting data was reduced within Nu Quant, as follows: groups of 40 consecutive $25.5 \mu$ s scans were initially summed within the software to give saved raw data points at $\sim 1$ ms displayed on a chart (ESI $\dagger$ ) with the correlating laser triggers displayed as markers in the data. A delay was attributable between the firing of the laser and the arrival of ions at the detector, this delay was applied to the demarking values in the data. The data collected before the first trigger signal was used to provide the gas background. The data between each delay corrected trigger was then averaged and background subtracted to provide a data point for each individual pixel. The ICP-MS software was able to demark the start and end of each line of the image by the difference in timing between laser triggers. Therefore, the pixels could be directly associated with each laser shot, with no blurring between pixels. The resulting element counts per second data was exported in CSV format for image visualisation and further processing.

\section{Data processing}

Images of the sector-field data were generated using 3DField. ${ }^{27}$ For TOF data, images were generated using in-house software; LA-ICP-MS ImageTool v1.7 (Reid-IT Limited, Loughborough, UK). ${ }^{21}$ In the TOF experiments, data for a large mass range (between $\mathrm{Na}$ and $\mathrm{U}$ ) was collected, but many elements in this range are not present in either asbestos or the MSTO-211H cells and gave rise to only background signal. Subsequent data analysis therefore focussed in on 10 elements that are either matrix constituents of the fibres or have been known to substitute into one of the fibre types studied $\left({ }^{23} \mathrm{Na},{ }^{24} \mathrm{Mg},{ }^{27} \mathrm{Al}\right.$, ${ }^{28} \mathrm{Si},{ }^{31} \mathrm{P},{ }^{39} \mathrm{~K},{ }^{40} \mathrm{Ca},{ }^{48} \mathrm{Ti},{ }^{55} \mathrm{Mn}$ and ${ }^{56} \mathrm{Fe}$ ). The outer boundary of each fibre was identified through visual inspection of the images. The signals within the boundary of each fibre were then summed for each of the 10 elements of interest. From these, ratios of the elemental signals within each fibre were calculated. Principal component analysis was performed on the resulting data using SIMCA ${ }^{\circledR}$ v16.0.1 (Sartorius, Umea, Sweden). Unit variate scaling was used to normalise the data as a preprocessing step before principle component analysis.

\section{Results and discussion}

\section{Visualisation of fibres in biological matrices}

Identification of fibres within biological samples is a complex challenge, since these matrices often contain background levels of the metals of interest. Initial studies sought to distinguish whether a sector-field instrument could provide multi-element analysis of a mixture of actinolite and amosite, sufficient to distinguish them from a typical cellular background. A standard laser ablation system was used in order to provide peak widths that were considerably longer than the time taken to scan across the selected mass range. The cells contained detectable levels of endogenous ${ }^{23} \mathrm{Na},{ }^{24} \mathrm{Mg}$ and ${ }^{31} \mathrm{P}$, which facilitated registration of the LA-ICP-MS images to the microscopy data (see ESI $\dagger$ ). Signals for ${ }^{24} \mathrm{Mg},{ }^{27} \mathrm{Al}$ and ${ }^{29} \mathrm{Si}$ in the fibres were above the cellular background, confirming that LA-ICP-MS is a viable technique for visualisation of the fibres within complex matrices. However, the instrumentation used for the feasibility experiment may be unable to meet the demands of large-scale research studies into asbestos in the long-term. The sequential nature of magnetic scanning in sector-field instruments restricts their ability to perform multi-elemental analysis on transient signals. This can be somewhat alleviated through the use of FastScan mode, which uses the ion optic deflectors to provide faster electric scanning. However, this mode comes at the expense of a restricted mass range (up to $40 \%$ of the parked mass of the magnet). In the present study, this meant that several major components of asbestos, notably ${ }^{40} \mathrm{Ca}$ and ${ }^{56} \mathrm{Fe}$, were not detected. The mode is also less suited to the very fast transient signals $(<10 \mathrm{~ms})$ from the latest generation LA systems. Clinical research requires high-throughput screening of tissues, which can be more readily achieved using these fast washout systems. The capability to differentiate between fibre subsets could therefore be enhanced by utilisation of a TOF spectrometer to provide pseudo-simultaneous detection of the full mass range.

\section{Differentiation of fibres}

Differentiation between fibre subsets was performed using a high-speed LA chamber, which produced peak widths of $\sim 10$ $\mathrm{ms}$, along with a prototype time-of-flight mass spectrometer. Fig. 1 and 2 show the resulting data for several characteristic elements in actinolite, amosite, crocidolite and wollastonite fibres. From their chemical formulae (Table 1), it can be seen that all four of the fibre types contain silicon as a matrix element. Thus, as was expected, strong ${ }^{28} \mathrm{Si}$ signals were observed for all four fibre types (Fig. 1 panels (I-L)), enabling rapid differentiation of the fibres from the cellular background. Magnesium was found to varying extents in all three of the asbestos fibres studied (Fig. 1 panels (E-G)), but only traces

Table 1 Nominal composition of the four fibre types studied

\begin{tabular}{lll}
\hline Fibre name & Fibre type & Nominal chemical composition \\
\hline Actinolite & Asbestos & {$\left[\mathrm{Ca}_{2}\left(\mathrm{Mg}_{,}, \mathrm{Fe}^{2+}\right)_{5} \mathrm{Si}_{8} \mathrm{O}_{22}(\mathrm{OH})_{2}\right]_{n}$} \\
Amosite & Asbestos & {$\left[\left(\mathrm{Mg}, \mathrm{Fe}^{2+}\right)_{7} \mathrm{Si}_{8} \mathrm{O}_{22}(\mathrm{OH})_{2}\right]_{n}$} \\
Crocidolite & Asbestos & {$\left[\mathrm{Na}_{2} \mathrm{Fe}^{3+}{ }_{2} \mathrm{Fe}^{2+}{ }_{3} \mathrm{Si}_{8} \mathrm{O}_{22}(\mathrm{OH})_{2}\right]_{n}$} \\
Wollastonite & Control & $\mathrm{CaSiO}_{3}$
\end{tabular}

${ }^{a}$ Natural asbestos may deviate from this composition. For example, in some varieties of amphibole, the elements may be partially substituted by $\mathrm{K}, \mathrm{Al}, \mathrm{Ti}, \mathrm{Mn}$ etc. 
were observed in the wollastonite control (Fig. 1 panel $\mathrm{H}$ ). The ${ }^{24} \mathrm{Mg}$ signals were strongest for amosite, where $\mathrm{Mg}$ accounts for $>20 \%$ of the nominal composition of its cummingtonite form. During analysis, a collision-reaction cell was used to reduce nitrogen and argon related interferences, enabling ${ }^{40} \mathrm{Ca}$ to be measured without interference from ${ }^{40} \mathrm{Ar}$ and ${ }^{56} \mathrm{Fe}$ to be measured without polyatomic interference from ${ }^{40} \mathrm{Ar}^{16} \mathrm{O}$ (see ESI $\dagger$ ). This proved to be advantageous because comparison of iron and calcium signals was highly effective in enabling differentiation between certain fibre types. Iron is present at varying percentage levels in the three asbestos fibre types, but it is not a matrix component of the wollastonite control. The distribution pattern of iron (Fig. 2 panels (I-L)) therefore enabled rapid discrimination between the three asbestos fibres and the control sample. Furthermore, calcium is a major matrix component of wollastonite, representing $\sim 35 \%$ of its nominal composition. Calcium is present to a much lesser extent in actinolite ( $\sim 9 \%$ of its nominal composition), but it is not a matrix component of the other two fibre types studied. Thus,

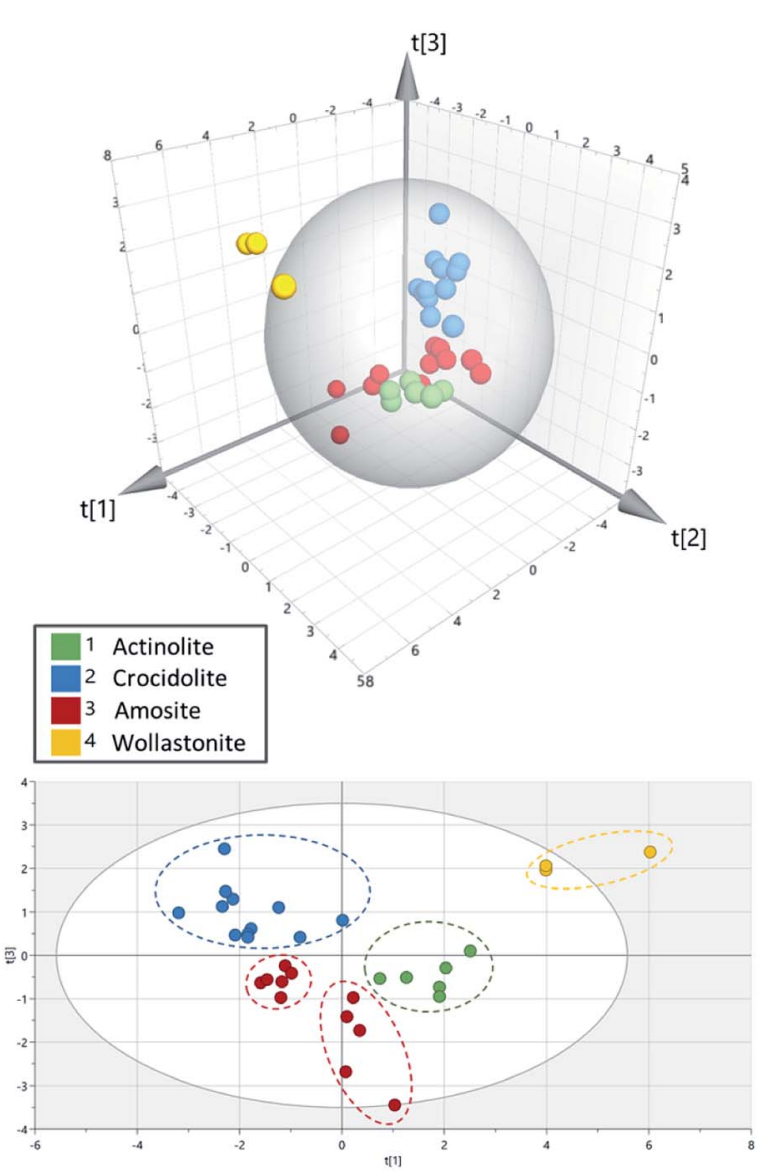

Fig. 3 Principal component analysis of a range of elements $\left({ }^{23} \mathrm{Na}\right.$, ${ }^{24} \mathrm{Mg},{ }^{27} \mathrm{Al},{ }^{28} \mathrm{Si},{ }^{31} \mathrm{P},{ }^{39} \mathrm{~K},{ }^{40} \mathrm{Ca},{ }^{48} \mathrm{Ti},{ }^{55} \mathrm{Mn}$ and $\left.{ }^{56} \mathrm{Fe}\right)$ in actinolite $(n=6)$, crocidolite $(n=12)$, amosite $(n=11)$ and wollastonite $(n=3)$ fibres, where $n$ is the number of fibres. The upper image displays a 3D representation of the three major principal components. A 2D model, showing the top 2 principal components, with clusters outlined in dotted lines, is displayed underneath. The grey ellipses represent Hotelling's T2 (95\%). crocidolite and amosite (Fig. 2 panels F and G) can be easily distinguished from actinolite and wollastonite (Fig. 2 panels $\mathrm{E}$ and $\mathrm{H}$ ) through visual comparison of the calcium images. The differences between amosite and crocidolite across Fig. 1 and 2 were more subtle. Sodium is a matrix component of crocidolite but not amosite, so analysis of sodium was also evaluated as a way to visually distinguish these two fibre types (Fig. 2 panels $\mathrm{B}$ and $\mathrm{C}$ ). However, the very high level of sodium in biological matrices e.g. the dense cluster of cells in image $\mathrm{B}$, along with the common use of PBS to prepare cell samples, may interfere with the interpretation of fibres. This serves to confirm that analysis of a single element would be insufficient to distinguish between these two fibre types. Principal component analysis was therefore employed as an additional approach to provide more in depth analysis of the differences across a range of elements. This revealed that the fibre types separate into 5 distinct groups
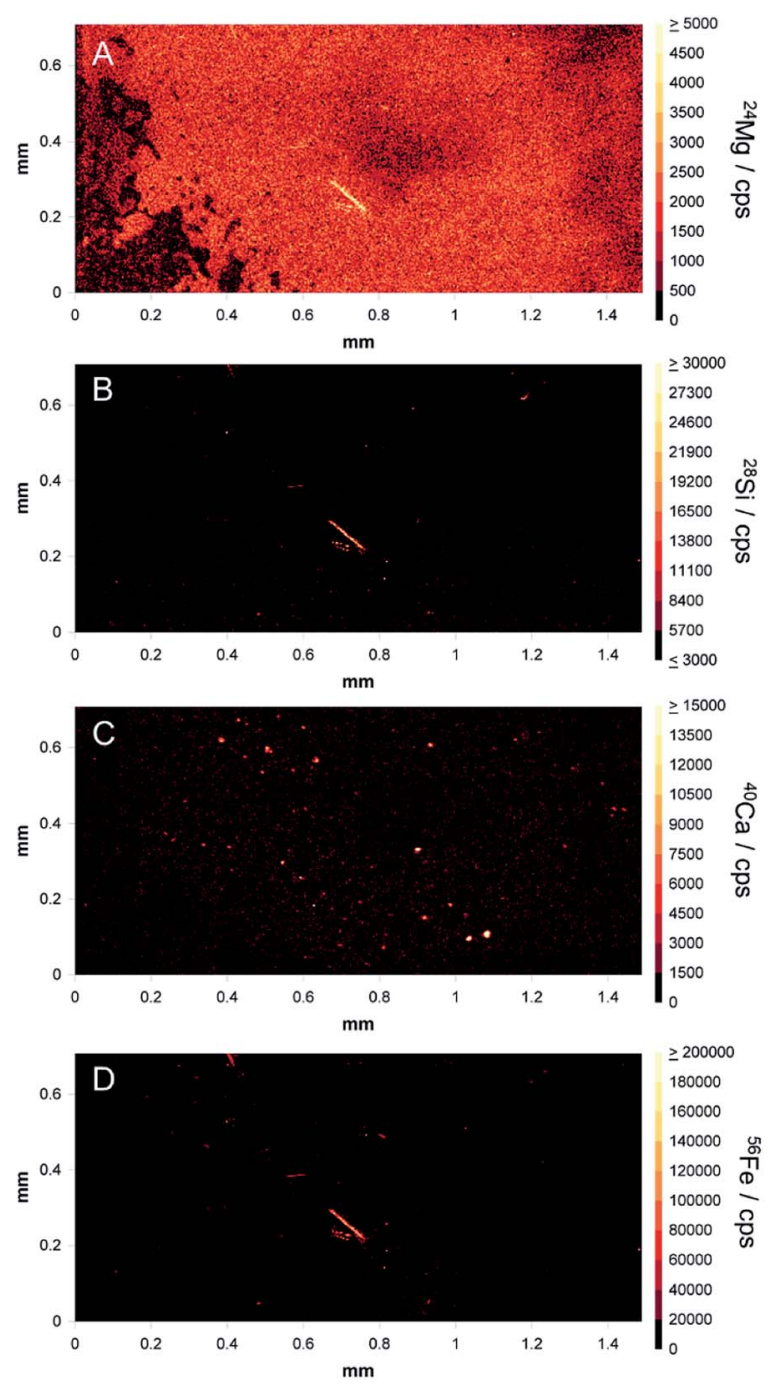

Fig. 4 MSTO-211H cells spiked with actinolite were pressed into cell pellets and sectioned before being presented for LA-ICP-MS analysis as a blind sample. Images of the magnesium (A), silicon (B), calcium (C) and iron (D) distribution revealed the presence of a large fibre, which was correctly identified as amosite. 
(Fig. 3). The wollastonite control fibres were well separated from all three asbestos fibre types in the PCA plot. Actinolite and crocidolite were also well separated from each other. However, the amosite fibres formed two distinct groups. Amosite is found in two forms (grunerite and cummingtonite), thus it is possible that a mixture of the two forms were present in the fibres analysed in this study. Acquisition of a larger data set would be required to verify this hypothesis.

\section{Analysis of 3D cultures}

After demonstrating that fibres could be distinguished in monolayer cultures, a cell pellet containing amosite fibres was prepared, sectioned and provided to the analyst as a 'blind' sample. The densely packed nature of the 3D cultures better mimics the conditions under which patient tissue are analysed. Fibres embedded within the cells are invisible to low penetration depth techniques, such as microscopy. However, the $193 \mathrm{~nm}$ laser successfully penetrated through the tissue, revealing one large fibre of approximately $120 \mu \mathrm{m}$ in length and some smaller fragments of below $50 \mu \mathrm{m}$ in length (Fig. 4). Magnesium, iron and silicon were observed in high amounts in these images (panels (A), (B) and (D)) with an absence of calcium signal (panel (C)). Analysis of the full range of characteristic elements enabled the analyst to correctly identify the fibres as amosite, demonstrating the potential of the technique for identification of fibres in complex tissue matrices.

\section{Conclusions}

This is the first study to use LA-ICP-TOF-MS to provide pseudosimultaneous multi-elemental analysis of fibres amongst a cellular background. The use of a low-dispersion ablation cell provided high-resolution, high-speed analysis, demonstrating that LA-ICP-MS has the potential to screen for the presence of fibre anomalies in clinical samples. It was apparent from the initial experiments that time-of-flight technology offers an advantage over sector-field technology for this application, particularly when used with high-speed laser ablation platforms. Use of the prototype ICP-TOF-MS system provided detection of the full range of significant elements within asbestos, which enabled an 'unknown' fibre, not visible under the microscope, to be correctly identified as amosite. This proofof-concept data presents an alternative to existing approaches for fibre characterisation and offers the possibility of conducting complementary LA-ICP-MS measurements within the same specimen. For example, identification of asbestos fibres in lung tissue may complement existing LA-ICP-MS measurements of candidate metallodrugs in lung tumours. ${ }^{16,28}$ It is estimated that only 6 of approximately 400 fibre types present in nature are regulated under the generic name of asbestos. ${ }^{29}$ Many more potentially carcinogenic fibres are unregulated and continue to cause human exposure and mesothelioma. Future multielemental LA-ICP-MS analysis of previously unstudied, candidate fibres would help to elucidate their role in the development of mesothelioma and other asbestos-related lung diseases.

\section{Conflicts of interest}

P. S. and A. D. are employees of Nu Instruments.

\section{Acknowledgements}

This research was supported by the June Hancock Mesothelioma Research Fund. Asbestos fibres were kindly donated by Santia Asbestos Management Ltd. Clinical support was provided by Professor Suvarna and Dr Kitsanta (Department of Histopathology, Royal Hallamshire Hospital, Sheffield, UK). The authors are grateful to Dr David Douglas and Dr Rob Hutchinson (Elemental Scientific Lasers) for their technical support with the laser system and Mr James Hough for his early assistance with this research. C. J. G. would like to thank Loughborough University for the provision of a funded $\mathrm{PhD}$ studentship.

\section{References}

1 F. Baumann, J.-P. Ambrosi and M. Carbone, Lancet Oncol., 2013, 14, 576-578.

2 W. Zhang, X. Wu, L. Wu, W. Zhang and X. Zhao, Ann. Transl. Med., 2015, 3, 182.

3 A. Bononi, A. Napolitano, H. I. Pass, H. Yang and M. Carbone, Expert Rev. Respir. Med., 2015, 9, 633-654.

4 IARC Working Group on the Evaluation of Carcenogenic Risks to Humans, A review of human carcinogens. Volume 100C: Arsenic, metals, fibres, and dusts, World Health Organisation, Lyon, France, 2012, https://monographs.iarc.fr/wp-content/ uploads/2018/06/mono100C.pdf.

5 P. De Vuyst, P. Dumortier, E. Moulin, N. Yourassowsky, P. Roomans, P. de Francquen and J. Yernault, Eur. Respir. J., 1988, 1, 362-367.

6 T. Ishida, M. Alexandrov, T. Nishimura, K. Minakawa, R. Hirota, K. Sekiguchi, N. Kohyama and A. Kuroda, Environ. Sci. Technol., 2010, 44, 755-759.

7 J. M. Dement, E. D. Kuempel, R. D. Zumwalde, A. M. Ristich, J. E. Fernback and R. J. Smith, Am. J. Ind. Med., 2015, 58, 494508.

8 L. Pascolo, A. Gianoncelli, C. Rizzardi, M. de Jonge, D. Howard, D. Paterson, F. Cammisuli, M. Salomé, P. De Paoli, M. Melato and V. Canzonieri, Microsc. Microanal., 2016, 22, 1062-1071.

9 L. Pascolo, A. Gianoncelli, G. Schneider, M. Salomé, M. Schneider, C. Calligaro, M. Kiskinova, M. Melato and C. Rizzardi, Sci. Rep., 2013, 3, 1123.

10 M. Scimeca, A. Pietroiusti, F. Milano, L. Anemona, A. Orlandi, L. T. Marsella and E. Bonanno, Eur. J. Histochem., 2016, 60, 2573.

11 H. Seyama, Y. Soma, M. Soma, S. Takao, T. Sakurai and S. Tagami, Fresenius' J. Anal. Chem., 1991, 341, 619-624.

12 D. P. Bishop, D. Clases, F. Fryer, E. Williams, S. Wilkins, D. J. Hare, N. Cole, U. Karst and P. A. Doble, J. Anal. At. Spectrom., 2016, 31, 197-202. 
13 M. Shariatgorji, A. Nilsson, M. Bonta, J. Gan, N. Marklund, F. Clausen, P. Källback, H. Loden, A. Limbeck and P. E. Andrén, Methods, 2016, 104, 86-92.

14 M. Cruz-Alonso, B. Fernandez, A. Navarro, S. Junceda, A. Astudillo and R. Pereiro, Talanta, 2019, 197, 413-421.

15 M. Bonta, H. Lohninger, V. Laszlo, B. Hegedus and A. Limbeck, J. Anal. At. Spectrom., 2014, 29, 2159-2167.

16 E. Karekla, W.-J. Liao, B. Sharp, J. Pugh, H. Reid, J. L. Quesne, D. Moore, C. Pritchard, M. MacFarlane and J. H. Pringle, Cancer Res., 2017, 77, 2029-2039.

17 D. N. Douglas, A. J. Managh, H. J. Reid and B. L. Sharp, Anal. Chem., 2015, 87, 11285-11294.

18 S. J. M. Van Malderen, J. T. van Elteren and F. Vanhaecke, J. Anal. At. Spectrom., 2015, 30, 119-125.

19 A. Gundlach-Graham, M. Burger, S. Allner, G. Schwarz, H. A. O. Wang, L. Gyr, D. Grolimund, B. Hattendorf and D. Günther, Anal. Chem., 2015, 87, 8250-8258.

20 S. Theiner, S. J. M. Van Malderen, T. Van Acker, A. Legin, B. K. Keppler, F. Vanhaecke and G. Koellensperger, Anal. Chem., 2017, 89, 12641-12645.

21 A. J. Managh and P. Reid, J. Anal. At. Spectrom., 2019, 34, 1369-1373.

22 M. Burger, A. Gundlach-Graham, S. Allner, G. Schwarz, H. A. O. Wang, L. Gyr, S. Burgener, B. Hattendorf,
D. Grolimund and D. Günther, Anal. Chem., 2015, 87, 8259-8267.

23 O. B. Bauer, O. Hachmöller, O. Borovinskaya, M. Sperling, H.-J. Schurek, G. Ciarimboli and U. Karst, J. Anal. At. Spectrom., 2019, 34, 694-701.

24 K. Löhr, O. Borovinskaya, G. Tourniaire, U. Panne and N. Jakubowski, Anal. Chem., 2019, 91, 11520-11528.

25 Cancer Cell Culture: Methods and Protocols, ed. I. A. Cree, Humana, New York, 2011.

$26 \mathrm{Nu}$ Instruments, Attom NAO5 (HR-ICP-MS), The Attom High Resolution ICP-MS: Fastscan Ion Optics for Rapid Isotope Ratio Measurements, www.nu-ins.com/products/hr-mc-icpms/attom-es, accessed 06/04/20.

27 3D Field, https://3dfmaps.com/3d_maps.htm, accessed 30/ $06 / 20$.

28 C. J. Greenhalgh, E. Karekla, G. J. Miles, I. R. Powley, C. Costa, J. de Jesus, M. J. Bailey, C. Pritchard, M. MacFarlane, J. H. Pringle and A. J. Managh, Anal. Chem., 2020, DOI: 10.1021/acs.analchem.0c01347.

29 M. Carbone, P. S. Adusumilli, H. R. Alexander Jr, P. Baas, F. Bardelli, A. Bononi, R. Bueno, E. Felley-Bosco, F. Galateau-Salle, D. Jablons, A. S. Mansfield, M. Minaai, M. de Perrot, P. Pesavento, V. Rusch, D. T. Severson, E. Taioli, A. Tsao, G. Woodard, H. Yang, M. G. Zauderer and H. I. Pass, Ca-Cancer J. Clin., 2019, 69, 402-429. 